\title{
Column Study of Nitrate Downward Movement and Selected Soil Chemical Properties' Changes in Mine Spoiled Soil as Influenced by Liquid Organic Fertilizer
}

\section{Z. Muktamar ${ }^{*}$, S.Y.K. Hasibuan, D. Suryati and N. Setyowati}

Soil Science Department, University of Bengkulu, Bengkulu 38371, Indonesia

Muktamar Z., Hasibuan S.Y.K., Suryati D. and Setyowati N. (2015). Column Study of Nitrate Downward Movement and Selected Soil Chemical Properties' Change in Mine Spoiled Soil as Influenced by Local Based Liquid Organic Fertilizer. Journal of Agricultural Technology 11(8):2017-2027.

Open pit coal mining is common practice to extract coal from lithosphere. This system, however, will bring about soil degradation. Organic fertilization is an alternative to recover fertility of the degraded soil. The objectives of the experiment were to determine nitrate downward movement and change of selected chemical properties in the soil column and to compare the growth of lamtoro (Leucaena leucocephala) as affected by local based liquid organic fertilizer. Column experiment was conducted using mine spoiled soil from Taba Penanjung Sub-District, Central of Bengkulu District, Bengkulu, Indonesia located at approximately $364.5 \mathrm{~m}$ above sea level. The experimental design was Completely Randomized Design with 3 treatments consisting of control, 75 and $150 \mathrm{ppm}$ of local based liquid organic fertilizer (LOF). The treatment was replicated 3 times. Soil column was prepared using PVC pipe with diameter of $12.5 \mathrm{~cm}$ and length of $40 \mathrm{~cm}$. Soil sample was put into the column and compacted by knocking the base of the column until the soil height achieved $35 \mathrm{~cm}$. Lamtoro was raised in the column for 11 weeks. At the end of experiment, lamtoro shoot was cut and the PVC column was cleaved horizontally and soil was pushed out from the column. Soil sample was, then, sliced into 6 fractions, representing depth of 0-5, 5-10, 10-15, 15-20, 20-25, and > 25 $\mathrm{cm}$. Fresh soil sample from each depth was extracted by distillated water and analyzed for $\mathrm{NO}_{3}-$ N. Remaining of soil samples was air-dried for 72 hours, grinded with $0.5 \mathrm{~mm}$ screen, and analyzed for available $\mathrm{P}$, exchangeable $\mathrm{K}$, soil $\mathrm{pH}$ and exchangeable $\mathrm{Al}$. The experiment indicated that local based liquid fertilizer significantly increased soil $\mathrm{NO}_{3}-\mathrm{N}$, available $\mathrm{P}$, exchangeable $\mathrm{K}$, soil $\mathrm{pH}$ and reduced exchangeable Al. Higher rates of LOF caused increase in selected soil chemical properties but exchangeable Al. However, $\mathrm{NO}_{3}-\mathrm{N}$ was potential to move downward to deeper depth of the soil profile. Change of exchangeable $\mathrm{Al}$, soil $\mathrm{pH}$ and exchangeable $\mathrm{K}$ was observed until 20-25 m depth of soil profile, but change of available $\mathrm{P}$ was detected only to $10-15 \mathrm{~cm}$ depth. Better soil chemical properties were followed by enhancement of lamtoro growth.

Keywords: Nitrate, column study, liquid organic fertilizer, mine spoiled soil

"Coressponding Author: Z. Muktamar; e-mail: muktamar1959@yahoo.com 


\section{Introduction}

Coal mining in the world has increased significantly in the last decades. Total coal world production in 2013 increased by $67.27 \%$ as compared to that in 1990. In 2013, Indonesia produced $489 \mathrm{Mt}$, fourth highest coal producer country in the world after China, USA and India (World Coal Association, 2014). This is an indication of high coal mining activity in the country.

Open pit mining with back filling method is commonly used to extract coal from lithosphere (Darmawan and Irawan, 2009). The system, however, causes soil deterioration. Chemical reaction of pyrite as by product generates acidic compound which in turn oxidizes to form sulfuric acid, ferrous sulfate, and associated toxic metal (Ibeanusi et al. 2012), leading to decrease in soil pH below 3.0 (Vahedian et al. 2014). Research conducted by Tripathi et al. (2012) and Maharana and Patel (2013) pointed out that coal mining also brought about to decline of soil organic-C, total-N, nitrate-N, ammonium- $\mathrm{N}$, extractable-P, root biomass and increase in bulk density.

Application of organic matter to soil is an alternative solution to improve quality of the degraded soil since organic matter amendment to soil enhances soil physical, chemical and biological properties. Decomposition of organic matter slowly releases significant amount of nutrient (Foth and Ellis, 1997), consequently increase in organic- $\mathrm{C}$, Total $\mathrm{N}$, extractable $\mathrm{P}$, exchangeable $\mathrm{K}$, $\mathrm{Ca}$, and $\mathrm{Mg}, \mathrm{NH}_{4}-\mathrm{N}$ and $\mathrm{CEC}$ (Smiciklas et al. 2008; Samaras et al. 2008; Kowaljow et al. 2010). Ammonium-N afterward transforms to nitrate-N through nitrification process. Previous study showed that $\mathrm{NH}_{4}-\mathrm{N}$ declined within 1-3 weeks after incubation of organic matter in soil, followed by increase in $\mathrm{NO}_{3}-\mathrm{N}$ (Burger and Venterea, 2008; Rutherford and Arocena, 2012).

In general, nitrate-N easily moves down to deeper depth of the soil profile. Lysimeter study of nitrate leaching on Alfisol conducted by Zhao et al. (2010) showed that higher rate application of nitrogen fertilizer caused higher $\mathrm{NO}_{3}-\mathrm{N}$ leaching through the lysimeter. Coarse soil texture provided higher nitrate leaching as compared to finer soil texture (va Es et al., 2006). Application of organic fertilizer is able to prevent nitrate leaching as compared to synthetic chemical fertilizer (Nyamangara et al., 2003; Hepperly et al., 2009). Mechanism responsible to lower leaching load from organic fertilizer is associated with lower nutrient release from organic matter and temporarily immobilization of nutrient in the microbial biomass (Lehmann and Schroth, 2003). Another research, however, indicated that nitrogen leaching load was higher when soil fertilized with red clover manure as compared to that with ammonium nitrate (Bergstrom. and Kirchmann, 2004). The experiment aimed 
to determine nitrate downward movement and change of selected chemical properties in the soil column and to compare the growth of lamtoro (Leucaena leucocephala) as affected by local based liquid organic fertilizer.

\section{Materials and methods}

\section{Experimental Design and Amendment.}

Column experiment was conducted from December 2014 to April 2015 employing completely randomized design. Treatments consisted of 0,75 , and $150 \mathrm{ppm}$ local based liquid organic fertilizer (LOF), with 3 replications. Liquid organic fertilizer (LOF) was man-made in Closed Agriculture Production System (CAPS) Research Station by mixing $20 \mathrm{~kg}$ fresh dairy cattle feces, 20 liters dairy cattle urine, $5 \mathrm{~kg}$ soil consisting of effective local microorganism, $10 \mathrm{~kg}$ green leaves of Tithonia diversifolia, 20 liter diluted effective microorganisms-4 (EM-4), sugar and fresh water to a total volume of 200 liters in blue container. The mixture was incubated for 3 weeks. After incubation, the mixture was sieved using white cloth and ready for application. Liquid organic fertilizer contained $240000 \mathrm{mg} \mathrm{l}^{-1} \mathrm{~N}, 144 \mathrm{mg} \mathrm{l}^{-1} \mathrm{P}$, and $3450 \mathrm{mg} \mathrm{l}^{-1} \mathrm{~K}$

\section{Soil Collection and Column Preparation.}

Soil sample at depth of 0-20 cm was collected from coal mine overburden of Danau Mas Hitam Coal Mining Company in Sub-District of Taba Penanjung, District of Central Bengkulu, Indonesia, located at around altitude of $-3^{\circ} 45^{\prime} 4.92 "$ and longitude $102^{\circ} 30^{\prime} 72$ ". Elevation of the site was approximately $364.5 \mathrm{~m}$ above sea level. Soil sample was composited from 4 sites, representing the area of 3 year- overburden spoil. The sample was, then, air-dried for 3 days and sieved with $2 \mathrm{~mm}$ screen. Soil contained $49.15 \%$ sand, $30.84 \%$ silt, $20.01 \%$ clay (loam textural classification), $0.61 \mathrm{mg} \mathrm{kg}{ }^{-1} \mathrm{NO}_{3}-\mathrm{N}$, $10.15 \mathrm{mg} \mathrm{kg}^{-1}$ available P (Bray I), $0.16 \mathrm{cmol} \mathrm{kg}^{-1}$ exchangeable $\mathrm{K}, 4.30 \mathrm{cmol}$ $\mathrm{kg}^{-1}$ exchangeable $\mathrm{Al}, 19.49 \mathrm{cmol} \mathrm{kg}^{-1}$ Cation Exchange Capacity and soil $\mathrm{pH}$ of 2.80 .

Soil column was prepared using PVC pipe with diameter of $12.5 \mathrm{~cm}$ and length of $40 \mathrm{~cm}$. Soil sample was put into the column and compacted by knocking the base of the column until the soil height achieved $35 \mathrm{~cm}$. Vermicompost at rate of $25 \mathrm{Mg} \mathrm{ha}^{-1}$ was incorporated in $0-10 \mathrm{~cm}$ depth of each soil column. The column was placed in $45 \mathrm{~cm}$ tall wooden rack and wetted to water holding capacity. 


\section{Greenhouse Operation.}

Lamtoro seed was soaked with diluted sulfuric acid for 10 minutes, then, saturated with water for 24 hours to break the dormancy. The seed was germinated in growing media pan consisting of top soil and vermicompost with ratio of 1:1 by volume, respectively. After 2 weeks, lamtoro seedling with 4-5 leaves was transplanted into soil column. Each soil column received $200 \mathrm{ml}$ of LOF every week for 11 weeks, according to each treatment. Instead of LOF, control soil column was wetted with $200 \mathrm{ml}$ of distillated water. Plant was watered if necessary with the same amount of water.

After 11 weeks, lamtoro plant was sampled by cutting the stem, weighed for shoot fresh weight, dried at $60-70^{\circ} \mathrm{C}$ for 48 hours and reweighed for shoot dry weight. Root sample was obtained during soil sampling by separating roots from soil carefully, dried at $60-70^{\circ} \mathrm{C}$, and weighed for root dry weight.

At the end of the experiment, the PVC column was cleaved horizontally and soil was pushed out from the column. Soil sample was, then, sliced into 6 fractions, representing depth of 0-5, 5-10, 10-15, 15-20, 20-25, and $>25 \mathrm{~cm}$. Fresh soil sample from each depth was extracted by distillated water and analyzed for $\mathrm{NO}_{3}-\mathrm{N}$ using spectrophotometer (Balai Penelitian Tanah, 2005). Remaining of soil samples was air-dried for 72 hours, grinded with $0.5 \mathrm{~mm}$ screen, and analyzed for available $\mathrm{P}$ (Bray I), exchangeable $\mathrm{K}$ (flame photometer), soil $\mathrm{pH}$ (electrometric using $\mathrm{pH}$ meter at water and soil ratio of 1:2.5 by weight), and exchangeable $\mathrm{Al}$ (neutral salt extraction by Thomas, 1982).

\section{Results and Discussion}

\section{Mine Spoiled Soil Quality Improvement}

Application of organic fertilizer had significant effect on selected soil chemical properties of mine spoiled soil. Improvement of the soil quality was indicated by considerable increase in soil $\mathrm{pH}, \mathrm{NO}_{3}-\mathrm{N}$, available $\mathrm{P}$, exchangeable $\mathrm{K}$, and significant decrease in exchangeable Al. At depth of 0-5 $\mathrm{cm}$, soil $\mathrm{pH}, \mathrm{NO}_{3}-\mathrm{N}$, available $\mathrm{P}$ and exchangeable $\mathrm{K}$ increased by $38.2 \%$, $555.7 \%, 152.8 \%, 812.5 \%$, respectively, after application of highest organic fertilizer rate. At deeper layer of soil column, however, increasing percentage was lessened. On the other, at the same depth, exchangeable $\mathrm{Al}$ declined more than two folds from 4.30 to $2.06 \mathrm{cmol} \mathrm{kg}^{-1}$ after application of highest LOF 
rate. It was also observed that the reduction of exchangeable $\mathrm{Al}$ at deeper soil layer was also lessened.

Soil quality improvement substantially benefits to availability of plant nutrients. Decrease in exchangeable $\mathrm{Al}$ and increase in soil $\mathrm{pH}$ will be more favorable for growth of lamtoro. Study by Muktamar et al. (1998b) showed that decline of exchangeable $\mathrm{Al}$ in acid soil due to application of cattle manure recovered root environment indicated by increase in root length and root dry weight, leading to raise of $\mathrm{P}$ uptake and cutting down of Al uptake by soybean.

\section{Nitrate-Nitrogen Downward Movement}

Application of LOF significantly influenced downward movement of $\mathrm{NO}_{3}$ $\mathrm{N}$ in mine spoiled soil as indicated in Figure 1. Nitrate-N was mostly accumulated at the depth of $0-10 \mathrm{~cm}$ where highest rate of LOF provided highest $\mathrm{NO}_{3}-\mathrm{N}$ as compared to other rate of LOF. Ammonium-N from organic matter mineralization will undergo nitrification process, producing $\mathrm{NO}_{3}-\mathrm{N}$ (Smith et al. 1993). This anion is easily leached to the lower part of soil profile. Figure 1 indicated that $\mathrm{NO}_{3}-\mathrm{N}$ moved downward to the depth of 20-25 cm from the surface when mine soil was treated with either 75 or $150 \mathrm{ppm}$ of LOF. Other possible way for the increase in $\mathrm{NO}_{3}-\mathrm{N}$ at lower depth was the movement of LOF itself to deeper soil column, then, mineralized to release $\mathrm{NO}_{3}-\mathrm{N}$. In depth study is necessary to elucidate this phenomenon. Thirteen month lysimeter study conducted by Zhao et al. (2010) showed that application of high $\mathrm{N}$ fertilizer input brought about substantial increase in $\mathrm{NO}_{3}-\mathrm{N}$ concentration of leachate, exceeding drinking water guideline.

Figure 1 also indicated that $\mathrm{NO}_{3}-\mathrm{N}$ downward movement of mine soil fertilized with $75 \mathrm{ppm}$ LOF was comparable to that of $150 \mathrm{ppm}$ and much higher $\mathrm{NO}_{3}-\mathrm{N}$ of mine soil fertilized with $150 \mathrm{ppm}$ LOF was retained at $0-5 \mathrm{~cm}$ depth as compared to $75 \mathrm{ppm}$. This finding indicated that higher application rate of LOF did not accelerate leaching of $\mathrm{NO}_{3}-\mathrm{N}$. 


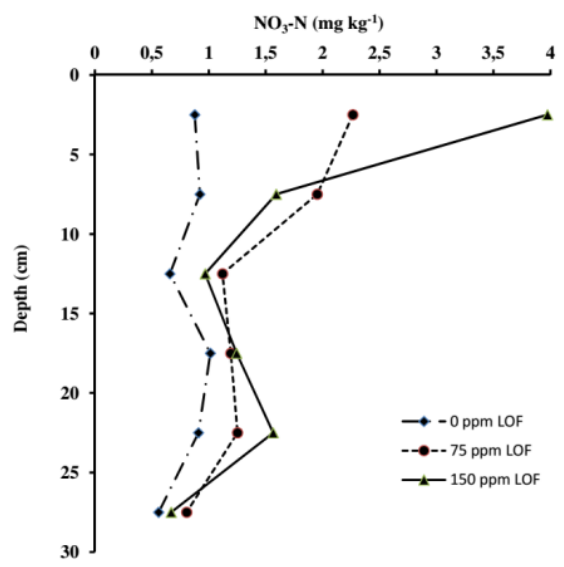

Figure 1. $\mathrm{NO}_{3}-\mathrm{N}$ downward movement in mine spoiled soil

\section{Exchangeable Aluminum Change}

Liquid organic fertilizer (LOF) application to mine spoiled soil significantly lowered exchangeable $\mathrm{Al}$ (Figure 2). It was observed that the decrease in exchangeable $\mathrm{Al}$ was distinguished up to the depth of $25-30 \mathrm{~cm}$ and higher rate of LOF caused exchangeable Al to decline more drastically. Exchangeable Al was substantially reduced at the depth of 10-25 cm depth through application of LOF. Application of $150 \mathrm{ppm}$ LOF reduced exchangeable Al by $60.7 \%, 35.5 \%, 149.7 \%, 104.7 \%, 587.1 \%$ and $4.4 \%$ at $0-5$, $5-10,10-15,15-20,20-25$, and $25-30 \mathrm{~cm}$ depths, respectively as compared to control. Degradation organic matter will release organic substances such as humic and fulvic acids, leading to complexation reaction with $\mathrm{Al}$ to form very stable Al-humic substance complexes (Muktamar, et al., 1998a; Spark, 2003; Wahyudi et al., 2010), therefore, exchangeable Al lowers.

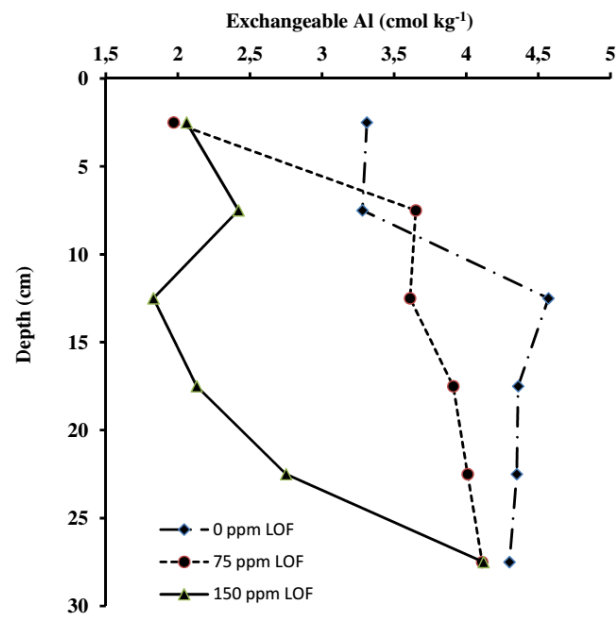


Figure 2. Exchangeable $\mathrm{Al}$ change as a function of LOF rates

\section{Soil pH Change}

The reduction of exchangeable $\mathrm{Al}$ as affected by $\mathrm{LOF}$ resulted in soil $\mathrm{pH}$ increase as indicated in Figure 3. Soil $\mathrm{pH}$ change was marked up to the depth of $20-25 \mathrm{~cm}$. and higher rate of LOF application did not significantly increased soil $\mathrm{pH}$. The highest increase in soil $\mathrm{pH}$ (from $\mathrm{pH} 3.40$ to 3.87) was reached by application of $150 \mathrm{ppm}$ LOF at depth of $0-5 \mathrm{~cm}$. The $\mathrm{pH}$ increase was lessened as deeper in the soil column. As humic substance and $\mathrm{Al}$ complex was formed, the solubility of $\mathrm{Al}$ in soil solution would decrease substantially, lowering production of hydrogen ion (Ifansyah, 2013).

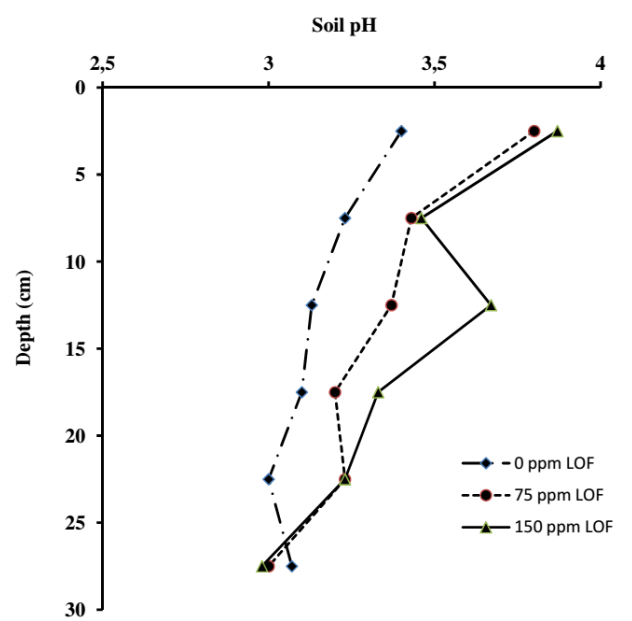

Figure 3. Change of soil $\mathrm{pH}$ as affected by application of LOF

\section{Change in Available Phosphorus}

Liquid organic fertilizer treatment to mine spoiled soil raised soil available phosphorus (Figure 4). Unlike other soil chemical properties, the effect of LOF was distinguished at upper $15 \mathrm{~cm}$ depth of soil column. Only was application of $150 \mathrm{ppm}$ LOF notable at depth of 10-15 cm. The effect of LOF was not detected below the depth. This might be associated with high solubility of $\mathrm{Al}$ in soil solution as indicated by high exchangeable $\mathrm{Al}$ at lower depth of soil column, causing reaction of $\mathrm{Al}$ and phosphorus to form stable aluminophosphate. This form of phosphate was not available to plant. Previous study conducted by Chardon et al. (2007) showed that total dissolved P was notable in leachate from $10 \mathrm{~cm}$ long soil column. 


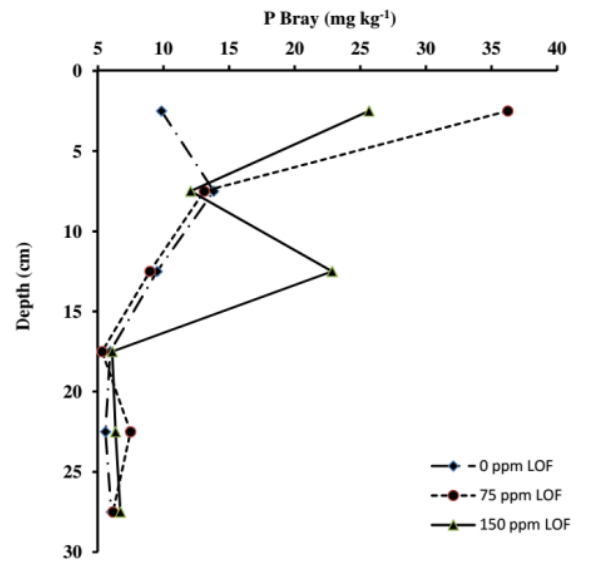

Figure 4. Change of soil available phosphorus as influenced by LOF

\section{Change in Exchangeable Potassium}

Soil exchangeable $\mathrm{K}$ significantly enhanced by application of LOF. Marked change of exchangeable $\mathrm{K}$ was observed up to $20-25 \mathrm{~cm}$ depth of soil column (Figure 5). Higher application rates of LOF resulted in significant increase in exchangeable $\mathrm{K}$ throughout the soil column but $25-30 \mathrm{~cm}$ depth. Exchangeable K of mine spoiled soil treated with $150 \mathrm{ppm}$ LOF raised by 1.86 , $2.30,4.84,1.50,3.75$ fold at depths of $0-5,5-10,10-15,15-20$, and $20-25 \mathrm{~cm}$, respectively, as compared to control. This pointed out that $\mathrm{K}$ was easily moved downward to deeper soil column. Previous study showed that substantial leaching loss was observed in foliage plant nursery (Broschate, 1995) and biochar could lessen leaching of $\mathrm{K}$ in soil (Widowati et al. 2012).

\section{Growth of Lamtoro}

Improved chemical properties of mine spoiled soil were followed by good performance of lamtoro growth as shown in Table 1. Application of LOF to mine soil significantly increased plant height, shoot fresh weight, root fresh weight, shoot dry weight and number root nodules. Mine spoiled soil treated with $75 \mathrm{ppm}$ of LOF provided best growth performance of lamtoro, even though it was not significantly different from that of fertilized with $150 \mathrm{ppm}$ of LOF. Number of nodules was exception where lamtoro fertilized with $150 \mathrm{ppm}$ of LOF significantly higher number of nodules than that of $75 \mathrm{ppm}$ of LOF. This might be related to better root growth as detected with slightly higher root fresh weight due to higher nitrogen supply from LOF $\left(240000 \mathrm{mg} \mathrm{N} \mathrm{l}^{-1}\right)$. Study by Munawar (1996) showed that lamtoro met requirement for coal mine soil reclamation since it was able to grow at degraded soil and recovered soil physical, chemical, and biological properties. 


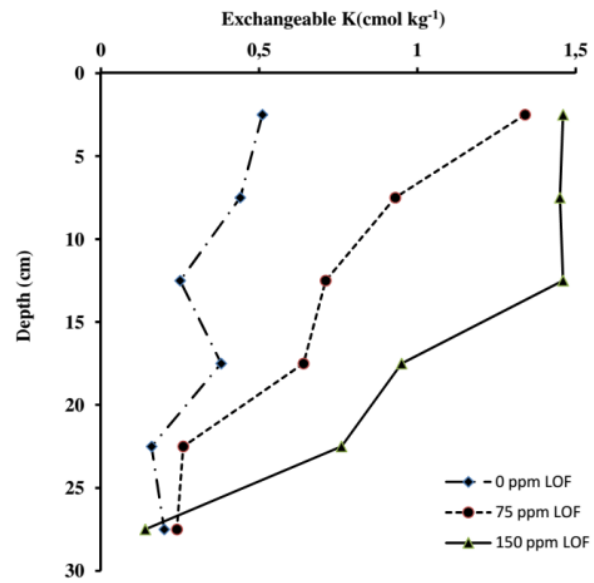

Figure 5. Exchangeable K change throughout soil column as a function of LOF.

In summary, Application of LOF significantly improved soil chemical properties of mine spoiled soil as indicated by increase in soil $\mathrm{NO}_{3}-\mathrm{N}$, available $\mathrm{P}$, exchangeable $\mathrm{K}$, soil $\mathrm{pH}$ and reduction of exchangeable Al. This improvement brought about better growth performance of lamtoro. However, $\mathrm{NO}_{3}-\mathrm{N}$ was potential to move downward to deeper depth of the soil profile. Change of exchangeable $\mathrm{Al}$, soil $\mathrm{pH}$ and exchangeable $\mathrm{K}$ was observed until 20-25 m depth of soil profile, but change of available $\mathrm{P}$ was detected only to 10-15 cm depth.

Table 1. Plant growth of Lamtoro as affected by liquid organic fertilizer

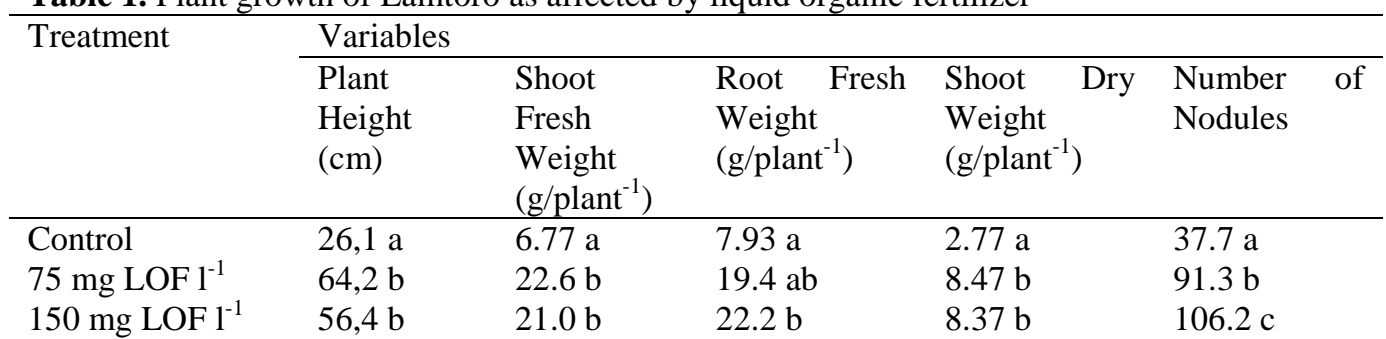

Treatment mean followed by the same letter within column is not significantly differences at $95 \%$ confidence level

\section{References}

Balai Penelitian Tanah. 2005. Petunjuk Tehnis Analisis Tanah, Tanaman, Air, dan Pupuk. Balai Penelitian Tanah (in Indonesian language).

Bergstrom, L. and H. Kirchmann. 2004. Leaching and crop uptake of nitrogen from nitrogen15-labeled green manures and ammonium nitrate. J. Environ. Qual. 33(5):1786-1792.

Broschate, T.K. 1995. Nitrate, phosphate and potassium leaching from container grown plants fertilized with several methods. HortScence 30(1): 74-77. 
Burger, M. and R.T. Venterea.2008. Nitrogen immobilization and mineralization kinetics of cattle, hog, and turkey manure applied to soil. Soil Sci. Soc. Am. J. 72:1570-1579.

Coal Producer Association. 2014. Coal Statistics. http://www.worldcoal.org/rsources/coalstatistics/ accessed 3 September 2015.

Darmawan, A. dan M.A. Irawan. 2009. Reklamasi lahan bekas tambang batubara PT Berau Coal, Kaltim. Proc. IPTEK Penyelamatan Hutan Melalui Rehabilitasi Lahan Bekas Tambang Batubara. pp: 17-26.

Foth, H.D. and B.G. Ellis. 1997. Soil Fertility, $2^{\text {nd }}$ Ed. Lewis Publishers. New York.

Hepperly, P., D. Lotter, C. Z. Ulsh, R. Seidel, C. Reider. 2009. Compost, manure and synthetic fertilizer influences crop yields, soil properties, nitrate leaching and crop nutrient content. J. Compost Sci. Util. 17(2):117-126.

Ibeanusi, V.M., E.J. Juandalyne Coffen and Y. Jeilani. 2012. Assessing Bioremediation of Acid Mine Drainage in Coal Mining Sites Using a Predictive Neural Network-Based Decision Support System (NNDSS). J. Bioremed Biodegrad 3(5):1-6.

Ifansyah, H. 2013. Soil pH and solubility of aluminum, iron, and phosphorus in Ultisol: Roles of humic acid.J. Trop. Soil 18(3):203-208.

Kowaljow, E., M.J. Mazzarino, P. Satti, and C. Jimenez-Rodriguez. 2010. Organic and inorganic fertilizer effects on a degraded Patagonian rangeland. Plant Soil 332:135145.

Lehmann J and G. Schroth. 2003. Nutrient Leaching. p. 151- 165. . In- Schroth G and Sinclair FL (eds.) Trees, Crops and Soil fertility - Concepts and Research methods. CAB International, Wallingford, UK.

Maharani J.K. and A.K. Patel. 2013. Characterization of physico-chemical properties and their impact on enzyme activities in a chronosequence coal Mine overburden spoil as biomarker of reclamation process. J. Bacteriol Parasitol 4(4):1-10.

Muktamar, Z, D. Aneri, and Suprapto. 1998a. Penurunan alumunium teradsorpsi pada tanah asam dengan sitrat dan oksalat. . J. Penelitian UNIB 11:1-4 (in Indonesian language).

Muktamar, Z., I. Candra, M. Chozin. 1998b. Pengurangan keracunan alumunium pada tanaman kedelai melalui pemberian pupuk kandang sapi pada tanah masam. J. Penelitian UNIB 11:39-45 (in Indonesian language).

Munawar, A. 1996. Reklamasi tanah pada lahan bekas tambang batubara di Bengkulu dengan revegetasi. Laporan Penelitian. Fakultas Pertanian Universitas Bengkulu, Bengkulu (in Indoensian Language).

Nyamangara, J., L.T. Bergstrom, M.I. Piha, and K.T. Giller. 2003. Fertilizer use efficiency and nitrate leaching in a tropical sandy soil. J. Environ. Qual. 32(2):599-606.

Rutherford, P.M. and J. M. Arocena. 2012. Organic amendments and earthworm addition improve properties of non-acidic mine tailings. Applied and Environmental Soil Science vol. 2012, Arti. ID 395964 pp. 1-11. Hindawi Publishing Corporation.

Samaras, V., C. D. Tsadilas, and S. Stamatiadis. 2008. Effects of repeated application of municipal sewage sludge on soil fertility, cotton yield, and nitrate leaching. Agron. J. 100:477-483.

Smiciklas, K .D. P.M. Walker, and T.R. Kelley. 2008. Evaluation of compost for use as a soil amendment in corn and soybean production. Compost Science and Utilization 16(2): 183-191.

Smith, J.L., R.I. Papendick, D.E. Bezdicek, and J.M. Lynch. 1993. Soil Organic Matter Dynamics and Crop Residue Management. p. 65-94. in F.B. Metting (ed). Soil Microbial Ecology: Application in Agricultural and Environmental Management. Marcel Dekker, Inc. New York.

Spark, D.L. 2003. Environmental Soil Chemistry. $2^{\text {nd }}$ ed. Academic Press. London. 
Thomas, G. W. 1982. Exchangeable Cation. p. 159-164. in A.L. Page, R.H. Miller, D.R. Keeney (eds.). Methods of Soil Analysis: Part 2: Chemical and Microbiological Properties. $2^{\text {nd }}$ Ed. ASA Publisher. Madison.

Tripathi, N., R.S. Singh, and S.K. Chaulya. 2012. Dump stability and soil fertility of a coal mine spoil in Indian dry tropical environment: A long term study. Environmental Management 50:695-706.

va Es, H.M., J.M. Sogbedji, and R.R. Schindelbeck. 2006. Effect of manure application timing, crop, and soil type on nitrate leaching. J. Environ. Qual. 35(2):670-679.

Vahedian, A., S. Asadzadeh Aghdaei, and S. Mahini. 2014. Acid Sulphate Soil Interaction with Groundwater: A Remediation Case Study in East Trinity. 2013 5th International Conference on Chemical, Biological and Environmental Engineering (ICBEE 2013) and 2013 2nd International Conference on Civil Engineering (ICCEN 2013). APCBEE Procedia 9. pp. 274-279.

Wahyudi, I., E. Handayanto, Syekhfani, and W.H. Utomo. 2010. Humic and fulvic acids of glirisidia and tithonia composts for aluminum detoxification in an Ultisol. Agrivita 32(3):216-224.

Widowati, Asnah, and Sutoyo. 2012. Pengaruh penggunaan biochar dan pupuk kalium terhadap pencucian dan serapan kalium pada tanaman jagung. J. Buana Sain 12(2): 83-90 (in Indonesian language).

Zhao, C., C. Hu, W. Huang, X. Sun, Q. Tan, and H. Di. 2010. Lysimeter study of nitrate leaching and optimum nitrogen application rates for intensively irrigated vegetable production systems in Central China. J Soils Sediments 10:9-17. 